\title{
Remembrance of the Colonial Past \\ in the French Islands of the Pacific: \\ Speeches, Representations, and \\ Commemorations
}

Bruno Saura

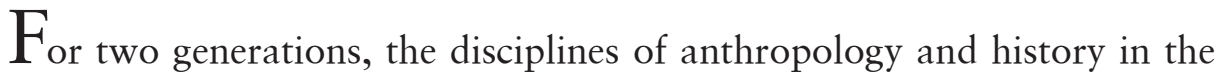
Pacific have been growing closer and at times serving to redefine one another. ${ }^{1}$ Now, in the early twenty-first century, the question of indigenous remembrances of the colonial past becomes a particularly rich point of encounter as anthropologists increasingly claim the duty of working on what used to be seen as historical matters, while historians are more and more open to (the practice of) "oral history." Geoffrey M White's works on the representations of the Second World War in the Solomon Islands and, more generally, in the Pacific region, are good examples of early steps in this direction of research (White and others 1988; White and Lindstrom 1989).

Recognizing remembrance as a subject of study in and of itself requires a clean break from classical epistemological approaches that emphasized the value of history as a science and largely discredited oral memories. Indeed, a canonical opposition can be felt between written, academic, and official history—with the qualities of a methodical discourse that aims to be objective and exhaustive-and remembrance, which, though it sometimes exists in written or tangible form, is fundamentally imprecise. Above all, remembrance tends toward forgetting: selecting as it does from among facts and characters, remembrance will only retain that which makes sense in the present, between the needs of the moment and those of tomorrow (see Nora I984).

Of course, even in the so-called West, we are called to move past the strict opposition between history and remembrance. Disciplinary history cannot claim to always be objective and exhaustive-it has often been (and

The Contemporary Pacific, Volume 27, Number 2, 337-368

(C) 2015 by University of Hawai'i Press 
at times still is) commissioned by specific persons, or influenced by those in power, or markedly shaped by the ideology and values of a regime. The long-held, popular idea that remembrance is plural because it is linked to groups (in contrast to history, which is a solid, coherent, and unified narrative) also deserves critical attention. There are certainly a thousand and one ways to write history and a thousand and one possible points of focus or ways of looking at the past. Take, for example, the many debates that have been raging since the early I960s about the definition of the history of the Pacific and in the Pacific, with a succession of schools and perspectives (Colonial History, Island-Centered or Islander-Oriented History, Indigenous Post-Colonial History, etc). Another example can be found in the recent historical controversies in France about the analysis of the relationship between the Republic and colonization, particularly in regard to remembrance (see Stora 2007; Blanchard and Veyrat-Masson 20I0).

The central question that they pose concerns the compatibility of the values of the French Republic (the Third Republic) and its colonial enterprise in the second half of the nineteenth and the first half of the twentieth century (1870-1940). As evident in the ideological representations dominant in France at the time, the Republican regime was supposed to be grounded in liberal and egalitarian values. However, the memory of an utterly unequal, racist administration in the lived experience of the colonized indigenous peoples of Africa, Asia, and Oceania bears witness to the perverse violence and injustice of the colonial regime and its supposed "values" on the ground.

The opposition between history and remembrance, already a loaded subject in the Western academy, is all the more fraught in Oceania, where only part of the official, academic history (and just in recent years, too) has been authored by indigenous people. Does it make sense to place "objective" history, written mainly by white people, on a pedestal while relegating indigenous (Kanak in New Caledonia, Mā'ohi in Tahiti) remembrance to the realm of mere emotions? That this opposition has become irrelevant may be taken for granted by a number of scholars investigating other islands and territories in the Pacific. It is not so, though, with all historians of New Caledonia and French Polynesia, especially those who live there or even who were born there. Aside from some notable exceptions-like the recent book on New Caledonia by Alban Bensa, Yvon Kacué Goromoedo, and Adrian Muckle (20I4) and, with respect to Tahiti, the older work of Jean-François Baré (1987)—research on autochthonous remembrances of the colonial past in those two territories are indeed few and far between. 
For that matter, they are more the work of anthropologists than of historians. This may possibly be accounted for by the small number of local historians who might have offered a different outlook on the history of their islands after completing their university training. For instance, the four natives of Tahiti who earned a doctoral degree in history in the last fifteen years (Anne-Lise Pasturel-Shigetomi 2000, Annick Pouira Lombardini 2003, Joany Haapaitahaa 2004, and Toriki Gleizal 2009) have relied primarily on written sources of Westerners, without relying much on or even consulting oral history.

This challenges us to consider the idea that, regarding French Polynesia and New Caledonia, it is absolutely necessary to respond to Robert Borofsky and his collaborators' invitation in Remembrance of Pacific Pasts: An Invitation to Remake History (2000). And in the desire to raise remembrance to the status of a scientific subject (just like history), the aim of this article is precisely to lay the foundations for an analysis of contemporary indigenous representations of colonial times in French Polynesia and New Caledonia. These representations are found in speeches and actionsmainly in commemorations organized by contemporary social and political figures. The work of remembrance is also expressed in artistic and literary works that others have studied. ${ }^{2}$ In this article, I mainly examine the remembrance of events, of "heroes" and remarkable episodes, rather than a more general experience of the colonial past-as studied, for example, by Marie Salaün in relation to the subject of school as colonial institution in New Caledonia (2005). I attempt to lay the broad outline for a more global study project-one that will address indigenous people's relationship to time and to the events reaching as far back as the arrival of white people in what have become the French islands of the Pacific. The variety of contemporary representations of this era, which will be referred to as the "colonial period" (or the "colonial past" or "colonial times"), could only be satisfactorily conveyed through extensive field research. Within the limited framework of this article, I focus on observations and informal conversations, with reference to the local press as well as religious publications in Tahitian. For lack of space, it has not been possible to discuss all island shores. A discussion of the remembrance of the time before the arrival of the first Westerners has been intentionally left out of the present study - a subject which, in relation to French Polynesia, I have addressed elsewhere. ${ }^{3}$ Finally, placing these reflections within a more general theoretical framework, I draw on concepts developed by French philosopher Paul Ricoeur in La Mémoire, l'Histoire, l'Oubli (2000). 


\section{Defining and Delimiting Colonial Times}

A few specifications should be made on the subject of "colonial times" and the concept of colonization, which may or may not include (for everything is a matter of delimiting, and thus of one's perspective on history) three processes or groups of phenomena that, in some islands, have taken place in different periods:

The first is the "appearance" of the Other: an Other simply passing through the Pacific Ocean at the end of the eighteenth century, or even (in some islands) one or two centuries earlier.

The second process concerns the arrival and then the settling of missionaries of various origins and nationalities, who had close or distant ties with State powers. They attempted to and in most cases succeeded in Christianizing Oceanians in the nineteenth century.

The third process is colonization itself; in this case the actions of the French state cannot be properly studied if we limit ourselves to a remembrance of France taking possession of the territory or of military acts that took place in the mid-nineteenth century. In what is now often referred to as the French Pacific, colonization includes the annexation of the Marquesas Islands in 1842 and the establishment, in the same year, of a French Protectorate on Tahiti (it was annexed in 1880 ); in New Caledonia, it includes France taking possession in 1853 , which immediately led to annexation. While there is necessarily a political and military side to the very definition of colonization, it is also a multidimensional phenomenon with significant demographic and economic aspects. It is also a process of cultural assimilation (in terms of language, education, judicial system, etc) that only began in these islands in the mid-nineteenth century. In this sense, colonization in Oceania is today ongoing.

In view of the distinction between these three types of processes, is it in fact justifiable to include phenomena that predated French colonization (in the I 840 o and I 850 ) within the terms "colonial times" or the "colonial past"? Frédéric Angleviel, a historian from New Caledonia (born into a community of descendants of French settlers, called Caldoches), proposed the term "prehistory" for the period prior to the arrival of white people in Oceania and the term "protohistory" for the period between James Cook's passage ( 1774 ) and France's seizure, or taking of possession (I853) (Angleviel 2007, 46). For him, the period anterior to French annexation is not included in his idea of colonization-or, in fact, of "history." Now, the term "protohistory" (and "prehistory" even more so, to 
my mind) carries a certain ideological slant. Why "protohistory," when written sources exist in New Caledonia prior to I 853 ? From my point of view, it does not seem appropriate to consider that the "history" of this territory begins only with French settlement. ${ }^{4}$ On the other hand, if we consider that the "colonial era" began in I 853 and not $\mathrm{I} 774$, we can understand Angleviel's point of view completely in the sense that before I 853 Kanak were not confronted with the same degree of violence, racism, and State intervention that they experienced once the French had settled in their territory. Still, another historical perspective might choose to subsume the "before-1853" (the period from I 774 to I853) in New Caledonia within the colonial period, on the basis that colonization is premised on an expansionist ideology and comprises an unequal distribution of material resources among those involved. In this sense, even the settling of merchants and missionaries before 1853 could be perceived as being part of the colonial past, or at least as coming from an "informal" imperialism of certain major European powers (see, on this subject, John Gallagher and Ronald Robinson's 1953 article, which introduced a distinction between formal Western colonizations or formal colonizations by "Western countries"- that is, political colonization—and "informal" elements of domination by "the West," for example, in commercial relations or in other fields or by other means of imperial domination).

In New Caledonia, from my point of view, periodization should no longer make the distinctions of prehistoric times (before 1774) and protohistoric times ( I774-I 853), which were followed by colonial times (beginning in 1853 ), but rather should simplify the division into precolonial times (before 1774) and actual colonial times (after I774).

Defining the conceptual and temporal limits of colonization has proved to be an even more sensitive exercise when speaking about the territory on the other side of the South Pacific-French Polynesia. In Tahiti and the Marquesas Islands, the work of Protestant emissaries from the London Missionary Society (LMS) began in I797-forty-five years before French colonization. Chronologically, nationally, and ideologically speaking, the work of these English missionaries was not strictly part of colonization, which was French and occurred later, by force. Indeed, the absence or presence of physical violence and the degree of subjugation of Oceanians are important factors for distinguishing between formal colonization and phenomena that often, in the Polynesian islands, preceded it. Native conversions to Protestantism in the beginning of the nineteenth century were voluntary, even if the populations did not immediately and unanimously 
obey the local chiefs who decided on them. These conversions happened prior to any political and military colonial presence. In the Austral Islands, the island of Rurutu had the first case of indigenous self-conversion in the Pacific (see Ellis I967 [1859], 393-403). Beginning in I821, inhabitants chose to adopt Protestantism, which some had just discovered in the Leeward Islands and which was seen as a religion of peace. When the LMS pastors disembarked in Rurutu the following year, the island had already renounced its traditional religion. Even in the Gambier Islands (in the southern part of the Tuamotu Archipelago), where evangelization was initiated in 1834 by French Catholic priests, conversions happened before the arrival of the French navy in the region and without political pressure; this is in contrast to the case of the Marquesas Islands, where conversion to Catholicism took place after the 1842 annexation by the French colonial power, which was in strong support of this conversion.

In the case of French Polynesia as well as that of New Caledonia, then, it is out of convenience, and perhaps for lack of precision, that we include various historical situations within the term "colonial times"instances when religious acculturation preceded actual French colonization. In this article I continue to use the term, however, since "colonial times"-whether referring to religious or military matters (and the difference is striking) — can generally be understood as a period when societies of unequal size and power were suddenly brought into contact with each other. This contact is followed by the establishment of more controlled relations, which lead, in most cases, to political colonization, initiated by a nation who brought some of the first foreign settlers to the islands or by another imperial power desiring to thwart the potential expansionist ambitions of the first.

\section{The Haze of Remembrance and First Contacts}

In the early twenty-first century, do the inhabitants of these islands make a distinction between the arrival of the Other, missionary work, and political colonial enterprises? Or do they rather subsume all these phenomena into a larger whole? One significant factor in people's responses to this question is whether they subscribe to an independence movement ideology that informs current representations of the past. Briefly, the indigenous people of New Caledonia and French Polynesia who are supporters of independence appear to be more likely than those who are not part of independence movements to maintain a certain critical distance when 
considering the "benefits" of Western acculturation, including religious acculturation, even though the question is an extremely complex one.

That said, the first point that is worth making (and a salient one at that), regardless of ideology or system, is related to the great silencethe general disinterest surrounding the first encounters-which mainly took place at the end of the eighteenth century. There are, of course, a few tablets or monuments here and there, erected through the initiative of municipal or tourism authorities, that remind us of the arrival of the first foreign ships-even though this "first contact" was often violent. In the Marquesas Islands, contact began in I 595 with the visit of Spaniard Alvaro de Mendana to Fatu Hiva, which ended with several dozen indigenous deaths. In Tahiti, soon after his arrival onboard the Dolphin in I767, Samuel Wallis was attacked by Tahitians in dugouts and used his cannons against them, again causing numerous deaths (Salmond 20II, 55-56). Visits to this island that followed were more peaceful, such as that of Louis-Antoine de Bougainville (I768) and those of James Cook ( $1769, \mathrm{I} 773-\mathrm{I} 774$, and I777). Cook was also the first European to establish contact with the Melanesians of "Grande Terre" (a name that distinguishes it from the "Loyalty Islands") in New Caledonia in September $\mathrm{I} 774$ in Balade.

Today, commemorations of these initial encounters are rare, and the Oceanians who are interested in the subject, for intellectual and professional reasons, are mostly educators. In schools in both New Caledonia and French Polynesia, adapted or "Oceanized" history and geography programs (which supplement or substitute for part of French programs) have only recently been put in place: in the late I980s in primary school and in the r990s in secondary school (and on Wallis and Futuna Islands, a few years later yet). Another cause for the "weakness of memory" about first contact is the fact that in the islands that have been subject to French acculturation, which has been contested for the past thirty years by indigenous identity claims (Kanak and Mā'ohi), the journeys of the first English navigators, in particular that of Captain Cook, were not the first steps in a historical process, leading to the birth of a nation, as was the case in New Zealand and Australia. At the time, however, the event or series of events surrounding the arrival of the first "dugouts without outriggers" in Eastern Polynesia are said to have fascinated indigenous peoples (see, in particular, Baré I985, I987; Dening I986) and to have been particularly meaningful to them. In Tahiti, the political situation was affected: maintaining contact with captains of foreign ships came to be a major factor in 
rivalries between chiefdoms. Nearly two and half centuries later (although it is true that countless ships have since passed by Tahitian shores), it is surprising that an event such as the transit of Venus in June 20I2, for the first time since Cook's voyage in I769, interested only a few Mā'ohi persons-and this despite promotion from local tourism and scientific authorities (who managed, in contrast, to attract thousands of foreign astronomers). Even the story of Ma'i (Omai) (McCormick 1977; Simmons 20I2; Ramsay 20I4), Cook's Polynesian companion on his second voyage, who traveled to Great Britain before returning to Polynesia and eventually dying in Huahine (Leeward Islands), is known by only a few locals. As a resident of Huahine for more than twenty-five years, I can personally testify that there is no tomb for $\mathrm{Ma}^{\mathrm{i}} \mathrm{i}$, nor is there any celebration of his memory. This is the case in Tahiti as well, where only a handful of philately fans, or patrons of a restaurant or bar named after him, are aware of Ma'i's story.

Should we read the distance surrounding remembrance of the first navigators, who were mostly English, as a consequence of more than a hundred and fifty years of colonization by the French? Actually, the I 768 passage of the French navigator, Louis Antoine de Bougainville-who also left for Europe with a Polynesian companion, Ahutoru—did not leave a strong mark on memory either, aside from the fact that the site where his boats were moored, on the east coast of Tahiti, is indicated in guidebooks. This may be because de Bougainville was arriving from South America and the objects he brought with him were mostly of Spanish origin-so Tahitians may have believed that his ships were Spanish vessels. His name has remained as a phonetic adaptation in Tahitian-putaveri or poutaveri, which refers to an ornamental plant: Tiare putaveri (bougainvillea). This name is also featured in a 1995 historical novel by Louise Peltzer (an academic and Huahine native), Lettre à Poutaveri (Letter to Poutaveri). The book retraces, with affection, amusement, and a complete lack of dissenting spirit, the arrival of the first white men in Tahiti and Huahine. Peltzer's work essentially pays tribute to the work of evangelization and literacy by English preachers from I797 onward in Tahiti (beginning in I 808 in Huahine). But Wallis is deliberately left out, and Bougainville is barely mentioned.

Until the recent setting up of an International Bounty festival, held for the first time in Papeete in October 20I3, the same statement about a "weak memory" of first contacts could be made about the travels of the famous "rebels" from the Bounty in I789-I790 in Tahitian and Tubuaian 
waters (Austral Islands), even though this is slightly better remembered than the passage of the previous navigators. Although the multiple works and films inspired by this story in the twentieth century are not well known to Tahitians, the shooting of the film Mutiny on the Bounty in 1960 is better remembered, especially because it led to the romance between American actor Marlon Brando and Tahitian actress Tarita Teriipaia. In Tubuai (Tupua'i in Tahitian), inhabitants who have read the Journal of James Morrison (1935) can tell visitors of the tragic clashes that marked the Bounty's two passages in I789-the site of its mooring, off the island's northwestern shore, was renamed Baie sanglante (Bloody Bay).

\section{Missionaries and New Historical Regimes}

There is one arrival that continues to be meaningful and the subject of storytelling by Tahitians today-the appearance, on 5 March 1797, of preachers from the London Missionary Society on board the Duff. They managed to convert the inhabitants of Tahiti and the neighboring islands in just over twenty years.

Over the decades, the date of 5 March 1797 has been celebrated within the Tahitian Protestant Church-a church that was originally missionary, became autonomous as the Evangelical Church of French Polynesia (Église Evangélique de la Polynésie Française, EEPF) in 1963, and was officially renamed the Maòhi Protestant Church (Église Protestante Maòhi, EPM) in 2004. ${ }^{5}$ These commemorations are similar to those on many other islands in the area (see Young 1996), celebrating the victory of the light of the Gospel over "times of darkness." In French Polynesia, a major innovation came about in the late I970s when commemorations of 5 March were transferred into the public sphere (through the initiative of the local government). After French Polynesia attained governmental autonomy within the French Republic in 1977, a new head of the country-Francis Ariioehau Sanford-was appointed. Sanford, a part-Polynesian Catholic originally from the Gambier Islands, set out to choose a holiday (besides the national I 4 th of July holiday) that could bring together the inhabitants from the five archipelagos of the territory. He chose the 5th of March, based on the widely held idea that the unity among French Polynesians stemmed from their faith in Christianity, a religion of peace. The 5 th of March soon became a national holiday, and its new name, "commemoration of the arrival of the Gospel in Tahiti," required just a few historical shortcuts. In fact, the Gospel was preached in Tahiti long before 5 March 
I797, by Catholic priests from South America, who set up the beginnings of a mission in the village of Tautira between I774 and I775, though without much success. Their memory continues to be celebrated occasionally, especially by Catholic authorities.

The idea that 5 March 1797 marked the arrival of the Gospel in Tahiti is thus shown to be a recent historical reinterpretation with nationalistic motivations. It is a point of pride for Protestants, whose missionaries were suddenly and officially promoted to the rank of historical ancestors of Christianity in Tahiti. Despite evolving representations, which are discussed below, the date of 5 March remains etched in Tahitian memory. It is familiar to everyone, unlike the date or even the year of the journeys of Wallis, de Bougainville, and Cook and also unlike other dates in nineteenth-century Tahitian history, such as the battle of Fe $\mathrm{c} i \mathrm{Pi}$ (between rival supporters and adversaries of Christianity, in I 8 I 5 ) or the consecration of the sovereigns from the Pomare family. It seems justified, then, to characterize 5 March as an "event" - not because of the immediate consequences but rather because of those that occurred in the middle and long term and taking into account the traces it has left on local remembrance and the evolving meanings conferred on it.

Jean-François Baré (1985, 1987)—who, like Marshall Sahlins (I985, I99I, I995), theorized the "event concept" in relation to the arrival of the Other in Polynesia-explained that 5 March I 797 was actually fairly unremarkable; for Tahitians, it was just the date when another British ship anchored in Matavai Bay, and they did not see in it any major religious significance. Its singularity was not felt during the time of conversions but rather years and years later, when this date began to be referred to as a founding memorial moment. The addition of a unifying nationalist aspect to the event in the late twentieth century constitutes another significant development, showing just how much—here as elsewhere-remembrance shows itself to be "an organization of forgetting," in the words of Paul Ricoeur $(2000,582)$. In the case of Tahiti, the forgetting relates to the earlier presence of Catholic missionaries.

In March 1997, the EEPF organized grandiose commemorations of the bicentennial of "the arrival of the Gospel in Tahiti," including assemblies, a colloquium, and even the publication of a book (EEPF I997). In the preface, Jacques Ihorai, EEPF president, referred to Christian acculturation in the following terms: "I would not dare say, as some might believe, that missionary actions in Polynesia were a source of harm for the practice and preservation of Polynesian culture! During their time here, faithful as they 
were to the Gospel, the missionaries never (as far as I know) imposed their culture and their knowledge on our tupuna [ancestors], but rather shared these freely. And if they did impose anything, it was certainly not with the intention to harm, but rather to encourage safety and security, in brotherly solidarity with the other" (EEPF I997, 6).

In contrast to the title of Nathan Wachtel's book on the conversion of Amerindians in Peru in the sixteenth and seventeenth centuries, The Vision of the Vanquished (I97I), it seems clear that Ihorai does not believe his ancestors were conquered by the Other through the process of Protestant religious acculturation in the nineteenth century. In contrast, a new theological movement began within the EEPF in the late I980s-one that casts the contribution of white people, including the missionaries, in a less positive light. In the book Poroì i te nūnaa màitibia e te Atua (Message to God's Chosen People), author Duro Raapoto (the main thinker of this new theological movement) placed the historical impact of the London Missionary Society in context, going so far as to say that "before the arrival of the missionaries, the Gospel of the Lord was already with the Māòhi" (hou te mau mitionare, ua tae ê mai na te Evaneria a te Atua io te Māòhi) (1989, 45). This statement, based on the natives' association of the Gospel with goodness and their understanding that it amounts simply to that which is good, was embraced and the idea has become widespread ever since in the EEPF/EPM, ${ }^{6}$ as well as for those outside the Church.

In addition to a general decreasing historical importance of white missionaries' arrival on 5 March I797, the end of the twentieth century was marked, within this Church, by a new insistence on Polynesian people's active role in their own conversions and in conversions on other Pacific islands; by the affirmation that the wives of missionaries also deserve recognition; and above all, by the great interest in a "prophecy of contact" by the visionary Vaita, who, not long before Wallis's arrival in Tahiti, foresaw the arrival of white men in these islands (Henry I928, 5).

Stories of predictions of the Other's arrival abound in Polynesia since European ships had been crossing the Pacific Ocean from the sixteenth century onward (Driessen I982). For those who are aware of this history, Vaita's prophecy is not, therefore, so spectacular, but it is interesting to note the attention it receives today (Saura I998). Is it because of its emotional charge-since it tragically affirms that Polynesian people knew their culture was destined to fade with the exposure to white people's way of life? But contemporary interpretations also read this prophecy as a story of religious revenge. The gift of Vaita the visionary demonstrates, in fact, 
the deep spirituality of the ancient Polynesians. Above all, his prediction inscribes the arrival of the Other within the logic of an indigenous historical continuity rather than in a movement initiated in the West. Michael Reilly, who analyzed two similar prophecies made in Mangaia (Cook Islands), expressed it well: the existence of these prophecies, as well as the success they had among indigenous peoples and sometimes among missionaries, shows that through them "the new religion and its practitioners were accepted into Mangaian society and, over the course of time, came to be seen as an extension, if not a continuation, of the earlier society, which they had, at first sight, overcome" (2005, I I9-I20).

In New Caledonia, similar theological developments can be observed over the last thirty years among Kanak Protestants, without, however, having led to the writing of so many theological texts in vernacular languages as there have been in Tahiti. In the early I990s, anthropologist Frédéric Rognon pointed out the tendency of pastors and other leaders in the Evangelical Church of New Caledonia to emphasize (in sermons and interactions) common points or "links" between the traditional religion and Christianity; this is done in order to explain nineteenth-century conversions and, we might say, to make them "less remarkable" (I99I, 39). He also noted that Protestants, in the past and still today, ${ }^{7}$ have a particular interest in "intuitions" and prophecies of contact:

Among these, the prophecy of Walewen à Fenefit (Lifou) is the most famous. From his deathbed [in I 852 ], he told Tupaisi and his children his last wishes in these words: "If one day speech enters the house from the North, do not let it in, because it is a baby moray eel that bites, and it has the 'gratte' [causes food poisoning]. But ... if one day speech arrives there, at the end of the hut (behind the firepit), then catch it, be careful not to let it go, because it's the child of a white turtle, and it will become a turtle.” This prophecy serves not only to justify conversion [to Christianity], but also the [specific] adoption of Protestantism. (Rognon I991, 39)

- since the Marist Priests and the French troops came to the chiefdom of Fenefit from the north of the island of Lifou, while the Protestant faith arrived from the south.

The theological developments that have been occurring for the past thirty years within Protestant churches in the francophone Pacific are not, however, reflected within other religious faiths. Within the latter, the remembrance of missionaries is colored by a certain reverence (even though there is a general trend toward a lessening of this reverence) and a 
stronger appreciation for local historical figures. Still, the case of Protestant churches remains the most significant because it shows the emergence of a new régime d'historicité (historical regime), to use the expression put forward by François Hartog (2003) with regard to our relationship to the past, by which he means a (contemporary) vision or perception or (de)valorization of the past. This regime is ethnocentric and downplays the import of events stemming from the West-or refuses to situate them within a causality defined solely by Westerners. In Tahiti, the transformation of the name and identity of the Protestant Church in 2004-when the Evangelical Church of French Polynesia became the Maòi Protestant Church-confirmed a significant shift. Up to that point, the community had been founded on the "fateful moment" of 5 March I797; after the renaming, it became a physical or ethnic community that "does not need any definition other than its own self-proclamation" (Bouju I995, II3, quoted by Candau I998, 87).

\section{“Specters" of Colonial Times in New Caledonia}

The relationship with French political colonizers is distinctly different from the relationship with religious leaders of the past since the former remain present and active in these islands. In New Caledonia, three key events mark the event of colonization and the disputes that accompanied it: the taking possession by the French in 1853 and the ensuing anticolonial uprisings of 1878 and I9I7.

It was in Balade that Admiral Auguste Febvrier-Despointes took possession of Grande Terre, on 24 September 1853 , in the presence of French Catholic missionaries and with the supposed approval of the main Kanak chiefs. A nearly identical ceremony took place five days later on the Isle of Pines. The Loyalty Islands were not taken over until a decade later, in June I864, by Governor Charles Guillain. Ceremonies were held in Maré and Lifou, with a confirmation in June I 865 in Ouvéa. These were followed by the establishment of a French political and administrative system; the organization of a process of settlements (penitentiary, in particular, as of I 864); the systematization of land seizure and the grouping of Melanesians on reserves (often in less fertile areas, since priority was given to the cultivation pursuits of white people); and the application of the Code of Indigenous Status to Melanesians. While other conflicts did happen in Grande Terre in 1856 and I870, the uprising of I 878 (on 25 and 26 June) was particularly tragic, involving the massacre of nearly a 
hundred European colonizers by men from the La Foa and Bouloupari clans under the command of Chief Ataii. The idea that Ataii also planned to attack the city of Nouméa on 24 September I 878 , on the twenty-first anniversary of French taking possession, has been much discussed (see Dousset-Leenhardt I970; Latham 1978; Saussol I985; Guiart I983; Dauphiné 1989). Colonial suppression and control led to hundreds of indigenous deaths and ended with the sacking of two villages, La Foa and Bouloupari, and then, because the Grand Chief Gélina de Canala rallied to the French cause, in the death of Ataï. He was killed on I September I 878 by a man from Canala, and his head was sent to Paris as a colonial trophy (see Fontanieu 20I3). ${ }^{8}$

These anticolonial incidents-and even more so, the events of I9I7illustrate the existence of major divisions within the Melanesian world. Multiple causes can be identified as having led to the clashes of I9I7 and the massacre, between the months of May and June, of European colonists in the Koné region. The fact is that Noël Néa Ma Pwatiba, chief of the Tiamou and symbolic figure of the uprising, was killed in January I9I 8 after a manhunt. The court case in Nouméa in I9I9 also showed the involvement of Grand Chief Bouarate from Hienghène "in a skilful manipulation that caused things to reach a fever pitch on the other side of the island in Koné,” as summarized by ethnologist Jean Guiart (20I 2, I4 I). Guiart also suggested an initial provocation by the colonists, who "desired to prevent their sons from being enlisted in the French troops with other members of their class and to leave for the front in France; in this way, they would need to remain in New Caledonia in order to help control events there" (2OI2, I42). Without calling into question certain of Jean Guiart's analyses, historian Adrian Muckle suggested that Guiart has consistently minimized the number of deaths (though these were mostly Kanak deaths) and the consequences of these events, which clash with the image of a unified Melanesian society. Muckle put forward the number of one hundred and thirty Kanak deaths in the I9I7 battles, plus five hundred deaths in prison. Sixty victims of epidemics should be added to this total (Muckle 20I2, I75).

In terms of the remembrance of these colonial and anticolonial events, it will not come as a surprise that 24 September-designated a national public holiday_has been celebrated since I 853 by the partisans of French New Caledonia with military and civilian parades. After the Second World War, when the winds of decolonization were blowing in the Pacific Islands, the organizers of the 1953 commemorations of the hundredth anniversary of French possession thought it would be a good idea to broaden their 
horizons a little, for example by promoting an opening of New Caledonia toward the outside world, in particular toward tourism (see Angleviel 2006, 90-92).

It was not until the last quarter of the twentieth century, with the emergence of a Kanak independence movement led mainly by the Front de Libération Nationale Kanak et Socialiste (FLNKS), that a memorial opposition to the colonial festivities of 24 September occurred-very publicly. In a real battle of remembrances on the local scale, the date came to be known as a day of mourning for Kanak people and also as a symbol of their resistance. The FLNKS was thus officially founded on 24 September 1984, and other symbolic events also took place on 24 September, such as the creation in 1985 of Radio Djiido, the radio station of the independence movement. While opposition to celebrations of the $24^{\text {th }}$ of September as a colonial holiday was always unanimous for Melanesian independence activists, the memory of the events of I 878 and especially of I9I7 remains a complex matter because of past divisions among Melanesians (for work on I9I7 and its memory, see ADCK 2008; Boubin-Boyer 2008; Bensa, Goromoedo, and Muckle 20I4). Muckle, who tackled this study, has called our attention to the "work of silence" that has been active since the court case of I9I9 ended, in a shared desire of all communities to overcome these tragic events (2012, I67-I9I). He noted, however, the resurgence fifty years later of public figures Ataï and Noël as "interchangeable symbols" of the anticolonial Kanak battles (Muckle 20I2, I78).

In New Caledonia, the tragedies of the I980s and I990s also led to new commemorative dates and a new "remembrance horizon," in a movement toward the future-that must nevertheless include the commemoration of recent dates when the promise of a peaceful "common destiny" was made. In a nutshell, the ethnic and political clashes from I984 onward that caused the deaths of dozens of people, most of whom were Melanesian independence militants, eventually led to the signing of the Matignon Accords in Paris on 26 June 1988 between the French State, representatives of the independence movement (led at the time by Jean-Marie Tjibaou), and representatives of the anti-independence movement (led by Jacques Lafleur). The accords were extended significantly on 5 May I998 with the signing of the Nouméa Accord, which strengthened the process of decolonization through a transfer of power, from the State to the territory, and ultimately paved the way to a referendum on self-determination. In terms of remembrance, the Nouméa Accord constitutes a clear recognition of colonial deeds: 
Preamble. I. On 24 September I 853, when France claimed "Grande Terre," which James Cook had named "New Caledonia," it took possession of a territory. . . . The treaties entered into with the customary authorities in I854 and subsequent years did not represent balanced agreements but were, in fact, unilateral instruments. This territory, however, was not empty. . . .

3. The time has come to recognise the shadows of the colonial period, even if it was not devoid of light. ...

4. The past was the time of colonisation. The present is the time of sharing, through the achievement of a new balance. The future must be the time of an identity, in a common destiny. (Australian Indigenous Law Reporter 2002)

In 2003 , at the time of preparations for the celebration of the one hundred and fiftieth anniversary of the 1853 annexation, certain associations such as the Comité I 50 Ans Après (the I 50 Years Later Committee) began working toward the transformation of this day into a moment focused on the future. The Comité I 50 Ans Après produced then a full history, "written from the Kanak point of view, including prophecies of the arrival of the great white ship, but also taking I 853 largely as its starting point” (Raylene Ramsay, pers comm, 20I4).

The idea that 24 September could become a celebration of citizenship was put forward in 2005 , since the Nouméa Accord instated a New Caledonian citizenship-which is still, for the moment, contained within the French Republic. A "war of remembrances" was begun through the erection of an immense Mwâ kâ (totem pole) on 24 September 2003 in Nouméa. The totem pole was carved by Kanak artists and carries elaborate symbolism, reuniting references to Melanesian culture and the multiethnic "common destiny" promised by the Nouméa Accord. Since the municipality (which is anti-independence) had not given its consent for the installation of the totem pole in the city center, it had to be temporarily placed elsewhere before being installed, in 2004, in front of the Museum of Nouméa. Numerous celebrations, commemorations, incidents, and quarrels occurred around the subject of this totem pole in the years that followed, with the Caldoche (white) community carefully avoiding it, at least at first (RI 2OI4).

The major change in this territory over the last twenty years is that colonial history is becoming the subject of a kind of "remembrance homework" for each community and also between communities, calling for a nuanced look at the past (whether one is part of the independence movement or not) in the desire for and the necessity of working toward a "common destiny" that would be more than a mere political slogan. Some- 
thing has shifted within the two main ethnic communities. On the basis of "repressed" memories—to borrow Paul Ricoeur's expression-that is, the painful memory of colonized Kanak populations and the long-held, shameful memory of the descendants of convicts ${ }^{9}$ - there is the attempt to create a future that is, if not happy, at least sustainable.

\section{The Memory of Wars of Resistance in French Polynesia}

The situation is different in French Polynesia, where the majority of the indigenous population (Mā'ohi) is not part of the independence movement, and where other communities (French and Chinese) are very much in the minority in terms of numbers. Here, pro-independence activists take the lead in the criticism of the conditions of French colonization in the nineteenth century as well as in the work of preserving the memory of the ensuing wars of resistance. The political divisions within the population prevent establishment of any consensus on the colonial past, aside from (very recently) the nearly unanimous condemnation by Tahitian political leaders of the French State's deceit regarding the nuclear tests-performed between I966 and 1996 on the Moruroa (or Mururoa) and Fangataufa atolls—and their supposed lack of adverse health impacts.

For the past thirty years, Joinville Pomare, a descendant of the Tahitian royal family, has headed the denunciation of the colonizers' lack of respect for the French protectorate treaty of 9 September 1842 and the treaty of annexation of 29 June 1880 . These treaties guarantee the protection of indigenous property and the maintenance of a traditional judicial system. Pomare's cause does not seem to be of great interest to most Tahitians today, who are more worried about employment and economic growth (the $20 \mathrm{I} 3$ vote in favor of Gaston Flosse's anti-independence party testifies to this) than about nineteenth-century history. Though he may seem to be behind the times, Pomare, in my opinion, is quite correct to condemn France's violation of these treaties and their equivalents on other islands (see Gonschor 2008). Although members of Oscar Temaru's independence party, the Tavini Huiraatira, often agree with the content of his speeches, they do not support Joinville Pomare's proposal to reinstate Tahiti's traditional chiefdoms (eliminated by his ancestor Pomare II in I 8 I 5 , even before French colonization, to strengthen his new position as absolute monarch). His suggestion that the monarchy be reinstated is even less popular.

The preservation of the memory of resistance to French colonization (in 
Tahiti and the Marquesas Islands in the I 840 s and in Raiatea [Leeward Islands] during the I 890s) is also very closely linked to independence militancy. Two years after Temaru's election to the Faaa municipal government (in 1983), local authorities unveiled a first monument to the Faaa natives killed during the colonial wars of $\mathrm{I} 844$. The date chosen was, symbolically, 29 June (I985). The monument, which is placed in a prominent location beside the road in a place called Tavararo, was built in the form of a marae (traditional pyramid-shaped sanctuary). Since then, other monuments have been installed here and there on the island of Tahiti, sometimes in very crude forms, such as the stone at the mouth of the Mahaena village river (east coast of Tahiti), placed by Joinville Pomare in $20 \mathrm{II}$ in memory of the Tahitians-several hundred at least-who were killed in a battle against French troops on I7 April I $844 \cdot{ }^{10}$

On each island where anticolonial battles took place, there are still people whose strong desire is for the memory of their ancestors to be remembered but not appropriated by members of the independence movement. In Nuku Hiva, the beginnings of a memorial consensus are starting to form around the figure of Pakoko, chief (haka'iki) of the Pakiu valley in Taiohae. Accused of causing the bloody assassination of French soldiers on 28 January I 845 , he was executed on $2 \mathrm{I}$ March of the same year. For a long time, his memory was suppressed because he had opposed the French presence, which, at the time, took the form of armed forces and the Catholic mission. The importance of Catholicism in the Marquesas Islands is well known—as in Wallis and Futuna. Sophie Humbert, who worked on archival documents and conducted studies in Nuku Hiva, presented an "episode from the past which evokes mixed feelings of pride and shame for the 'Enana (Marquesans) [since] that which concerns Pakoko also concerns ... religion. It is the Church that has written Marquesan history since it arrived. And it is the Mission that owns most of the land" (2003, I24; see also Humbert 2009, 37). Nonetheless, time has passed and the inhabitants of Nuku Hiva are beginning to take an interest in the memory of Pakoko, which was first celebrated-beginning at the end of the first decade of 2000 - by a few independence supporters of Tavini Huiraatira.

A fairly similar case of "memorial restoration" concerns Hapaitahaa a Etau, called Teraupoo, a symbolic figure of the resistance to French annexation by some of the inhabitants of the island of Raiatea (proclaimed in March I 888). Teraupoo was captured on the night of I 5-16 February I 897 by two Polynesians in the service of the French army, after nine years of scattered confrontations and an intensive six-week war that ended in 
nearly fifty deaths, mainly on the Polynesian side. Condemned in Papeete by Governor Gustave Gallet, Teraupoo was immediately deported to New Caledonia along with a dozen or so main figures of the resistance from Raiatea and Tahaa, while more than seventy men, women, and children were placed under house arrest for several years in Ua Huka (Marquesas Islands). Beginning in I997-the hundredth anniversary of this tragedythe memory of Teraupoo and his supporters began to be the subject of public demonstrations in his village, Tevaitoa-part of the Tumaraa municipality in Raiatea. It was also nearly a century later that his indirect descendants (Teraupoo died in 1918 in Raiatea, without any immediate descendants) began to speak about the taunting they endured in their childhood because they were members of the family of Teraupoo 'orure hau (Teraupoo the rebel). ${ }^{11}$ It is true that his fairly rare first name and surname-especially Te-rau-upo'o (the leaf/the greenery of/for the head) lends itself to multiple interpretations. One of his descendants, Teddy Tefaatau, mayor of Tevaitoa at the time, explained that his "great great uncle was called Teraiupoo, coupeur de têtes ['executioner' or 'headsman'-literally, head cutter]. We preferred [to interpret it as] Tera-upoo, 'this head'” (Besse 2010). Multiple rumors drift across the island on the subject of Teraupoo: many people think and say that he died in the penal colony in New Caledonia, which is not true (he was simply confined with the others who were deported to the east coast of Grande Terre, and in 1905 he came back to Raiatea, where he died in I9I8). The fact that his tomb is no longer visible today-having been, accidentally or not, covered over by the paving of a road-may lend support to those who believe that he did not die in Raiatea. Other "legends" surround the memory of his supporters who were exiled to Ua Huka. Their number was estimated at five hundred by Swiss pastor Paul Huguenin in his book Raiatea la sacrée (Raiatea the Sacred) (2007 [I902], 2 I0). Anne-Lise Pasturel's historical writings show, in contrast, that they were less than two hundred in number and that some were pardoned after months of exile $(2000,354)$. The contradictions between sources lead some contemporary independence supporters to believe and maintain that several hundred people from Raiatea were secretly deported in I897-or rather, thrown into the sea between Tahiti and the Marquesas Islands. Information about these commemorations was recently received from a member of the Teraupoo family who participates in the annual commemorations of the Raiatea war, during which tribute is paid to the memory of the "nameless victims" and other "hidden" victims of the conflict. Locally, in the village of Tevaitoa, the memory of Teraupoo as well as that of a 
brave warrior from the same period, Matahi tane, continues to inspire traditional dance and singing groups.

\section{The “War of Memories” of Tahiti’s Annexation}

In Tahiti, 29 June I880, the date of France's annexation of the Pomare kingdom, has been the subject of heated arguments for over thirty years. In 1985, Gaston Flosse, president of French Polynesia, decided to create an official public holiday called the fête de l'autonomie (Autonomy Day). The previous year, French Polynesia had been granted autonomous status anew, which expanded its authority compared with the status granted in 1977. With his proposal for this significant change in the meaning of the 29th of June (the annexation of I 880), Flosse's intention was to signify that colonial times were over, leaving room for a relationship of trust between Polynesia and France. Since 1985, this "manipulation" of the memory of the annexation has been criticized by independence supporters, who continue to see 29 June as a day of mourning, commemorated by songs, speeches, and prayers.

Oscar Temaru, elected president of French Polynesia in 2004, soon made it known that he wished to put an end to the 29 June celebrations. In 2006, a party of "autonomists" (supporters of French presence) protested his official plan to stop these celebrations by organizing a huge rally in Papeete. A monumental stone "tablet of autonomy" was placed in the middle of a roundabout, renamed "Autonomy Square" by Michel Buillard, mayor of the city. Since then, this intersection has often been used as a locus of 29 June commemorations; it was there three years later, on 29 June 2009, that Buillard gave a distinctly anti-independence speech:

Polynesian society today is diverse and rich. It is extremely mixed, and cannot be subsumed into a ma'ohi identity ...29 June I 880 is not a day of mourning, and Pomare V did not shamefully sell his country, as some will try to make us believe. On the contrary-in the context of the time, Pomare V showed great humility, courage and sacrifice. His decision certainly cost him a great deal, but it saved his people who were poised on the edge of extinction. It allowed them to get reborn, to flourish and grow in peace and security. Of course there were difficult moments. We must acknowledge that France did not respect all the terms of this alliance. (La Dépêche de Tahiti, 30 June 2009)

During the decade between 2000 and 2010 , the city of Papeete was the scene of multiple commemorative battle reenactments. In 2006, Temaru's 
government responded to Buillard's placement of the "tablet of autonomy" with two strong measures (La Dépêche de Tahiti, 29 June 2006). They announced that Avenue Bruat, the street in Papeete where most of the territory's official buildings stand, would be renamed Avenue Pouvanaa Oopa. While Armand Bruat, governor of Établissements Français de l'Océanie (French Colonies in Oceania) from I 843 to I 847 , was a central figure of repression during the first Tahitian wars of resistance to colonization, Pouvanaa Oopa, deputy in the National Assembly of France from I 949 to I958 and senator in the French Senate from I97I until his death in 1977 , is indisputably the father of contemporary Tahitian nationalism. Concurrently, Temaru's government authorized the placement of a monument commemorating the forty years since the first French nuclear test on 2 July I966, at another roundabout in the city, by the Moruroa e Tatou association of former workers on the nuclear site. On this score, in June 20I4, the territorial government of Gaston Flosse was making a historic turnabout. It decided to take over from the Moruroa e Tatou association the management of the waterfront site where its members in $2006 \mathrm{had}$ erected the antinuclear memorial of 2 July 1966. Ever the heir of a past of nuclear entente with France, Flosse went so far as to have his majority in the Assembly of French Polynesia approve (by 38 votes out of 57), on 24 June 2014 , the naming of the site as "Place Jacques Chirac"-Jacques Chirac, a conservative politician and a long-serving prime minister, had given the order in 1995 to resume French nuclear tests for a final year. As for the Moruroa e Tatou association, it was offered in June 20I4, by way of compensation, the possibility of setting up a different memorial for nuclear test victims, in a less-visited neighborhood in downtown Papeete.

Regarding the memory of Pouvanaa Oopa, the beginning of the twenty-first century saw a real process of rehabilitation, even of heroworshipping that historical character. Yet he had been despised in the I950s by some of the bourgeoisie and "Demis"-locally called Afa, or half-Polynesian half-European people-to whom a number of Tahitian politicians are linked today, ideologically and also through family ties. $\mathrm{He}$ was arrested in October 1958 on charges of being an accomplice in several instances of attempted arson in Papeete, although he had been asleep in bed on the night of these attempts (see Saura 1997). Convicted in I959, he was exiled to France for nearly nine years. There is no doubt today that Pouvanaa Oopa was the victim of a false arrest and an unfair trial; it is also very likely that he was framed. It remains to be seen whether the plot against him was organized locally, mainly by his Tahitian adversaries, 
or whether it was decided at a higher level by the French State to facilitate the setup of the Centre d'Expérimentations (nucléaires) du Pacifique (Pacific [nuclear] Tests Center, or CEP), which was officially announced in 1963. The thesis linking the deputy's arrest to the setup of the CEP has been increasingly developed by French historian Jean-Marc Regnault (I996, 2003, 2006; see also Regnault and Vannier 2009). It was also discussed by the Assembly of French Polynesia during the months of July 2009 and February 2013. Its members voted unanimously on a motion requiring the French minister of justice to bring the matter before the Commission de révision des condamnations pénales (Criminal Conviction Review Committee) so that Pouvanaa Oopa's sentence, handed by the Papeete criminal court on 2I October I 959 might be reversed. On I 8 June 20I4, Minister of Justice Christiane Taubira formally signed off on the review procedure.

As to the nuclear tests, they remain a constant bone of contention between Tahitian independence supporters-who, more and more, are joined on this point by many people who are anti-independence-and the French State, whose authorities, after having denied the tests' detrimental health effects for so long, continue to downplay them. It is possible to apply François Hartog's theory of periodization in three stages to Polynesian memory of these tests, which occurred so recently. In terms of the pace at which memories appear in the public space, Hartog suggested that a period of initial denial is followed by a period of struggles for memorial recognition, and finally a phase of acceptance, which varies in length, completeness, and difficulty, for the powers that be (Hartog 2003). Indeed, in French Polynesia, the decades from I960 to I990 saw a massive denial of the dangers of nuclear power by French authorities and their Tahitian political supporters. The phase of memory work corresponds to the late I 990 s and the early 2000s, when the Moruroa e Tatou association was founded and its actions began to bear fruit. In contrast, another association of former workers on the nuclear site, Tamarii Mururoa, developed a narrative that was almost nostalgic about what Polynesians experienced during the thirty years of nuclear tests. ${ }^{12}$ The third phase, that of the reception of the work of remembrance and its official acceptance by the State, has only just begun. It calls for apologies and compensation measures as well as overall recognition, by the State, of the "nuclear fact" (in the same way that historians often speak of the "colonial fact").

In terms of the memory of "colonial times" or the "colonial past," the situations of the two main French colonies in the Pacific are quite 
contrasting. Although the period of encounter with the first Western navigators is not of much interest to indigenous peoples in either case, and although the work of evangelizing by nineteenth (and sometimes twentieth) century missionaries tends to be represented in a favorable light in both cases, the colonial experiences and the representations of them are markedly different.

Until only recently, New Caledonia witnessed a violent past with clashes between some Kanak and the French colonizers, as well as among Kanak people. A tremendous amount of remembrance work is necessary in order for each clan and each ethnic community to learn its past, mourn its lost leaders, and acknowledge and turn the page on the less glorious episodes of its history. Indeed, history-meaning historical science, which is to say the narration and analysis of past events-has long been the subject of a certain mistrust in New Caledonia, just as much on the side of Caldoches (Merle I995, 368) as of Kanak (or at least, for the latter, Kanak history written by white people). ${ }^{13}$ For over a generation, the Matignon Accords and the Nouméa Accord have created a dynamic that forces us to look closely at the colonial past. This can be called real "remembrance work," a delicate exercise, in which Paul Ricoeur sees the limits of both "the good use and the possible abuse" of memory (2000, I06). However, these accords with the French State are the basis of the legacy of colonization, a little like the I 840 Treaty of Waitangi in New Zealand, which was initially contested by some Māori nationalists but in the late I970s became a foundation allowing people to acknowledge and, ideally, to put colonial times behind.

The case is different in French Polynesia, where debates about the colonial past do not mobilize the masses, aside from debates about land issues. Although New Caledonian identity is fundamentally a political construct, identity in French Polynesia seems to be expressed through the protection of local languages and through cultural practices, without the need for constant evocation of memories of the colonial past in order for people to define themselves or hold dialogue with the Other. Yet, the political instability after World War II, and in particular the State's lies about the nuclear tests, have created the present need to know, conducive to the necessity for work of reparation. Without the State's acknowledgment of its historical mistakes, no forgiveness is possible. In the eyes of independence supporters, and even outside their ranks, forgetting proves impossible and forgiving is a difficult task, one that first requires the State's acknowledgment of its wrongdoings. Oscar Temaru's long battle, won in 20I3, to put French 
Polynesia back on the United Nation's list of countries to be decolonized, is in accordance with the wished-for signing of Tahitinui accords which, much like the Matignon and Nouméa accords, would help pave the way to the future while acknowledging the past. Without this, there is a great risk that French Polynesia will become locked in a "bad memory" of its recent past: a wounded memory, pushing it to multiply commemorations and reinforcing a feeling of victimization. Between an "excess of memory" and an "excess of forgetting," the path is narrow, the task perilous and never complete.

I WOULD LIKE TO ACKNOWLEDGE Jessica Moore for translating this article from the French and also Isabelle Merle (CREDO, Marseilles) for the corrections she brought to it. I am indebted to Gerard Finin (Pacific Islands Development Program, East-West Center) and Terence Wesley-Smith (Center for Pacific Islands Studies, University of Hawai'i at Mānoa) for their warm welcome during my seven-week stay in Honolulu in late 2013. This gave me the time to write this article as well as to begin a book manuscript on the same topic, which will be published in Tahiti by Au Vent des Îles at the end of 2015. Also at UH Mānoa, all my thanks to Lorenz Gonschor and David Chappell for our thrilling and passionate conversations about Pacific history and to Alexander Mawyer and Jan Rensel, who worked so hard and so efficiently editing not only this article but also the whole special issue.

\section{Notes}

I See, eg, Sahlins I985, I995; Thomas I989; Biersack I991; Lal I992; Linnekin I997. In French, see Merle I999; Merle and Naepels 2003.

2 See André and Marchetti 2004; André 2008; Mokaddem 2008; Ramsay 20IO, 20II, 20I4; Sultan 20I I; Picard 2008; Vigier 201 I.

3 See Saura 2008, 389-435. More generally, and specifically on the subject of the Hawaiian Islands, see Friesen $200 \mathrm{I}$.

4 About New Caledonia, Bronwen Douglas stated that what she called colonial history "refers to all the phases of interaction between indigenous peoples and Europeans, from the first contact until decolonization. The use of this term only emphasizes the fact that European texts are of utmost importance for the writing of such a history" (I996, I 25).

5 The official name of the church uses the spelling "Maòhi," following the orthography developed by linguist and theologian Duro Raapato, who used the 
spelling "Māòhi" to refer to the indigenous people and language. Other linguists and scholars use the macron and glottal stop: "Mā'ohi."

6 Wilfred Pomare (brother of Joinville Pomare), one of the pretenders to the Tahitian royalty "throne," stated, for example, that "Tahiti has always been a Christian country, even before colonization God is the same for everyone. It's just that we are Christian Ma'ohi. We have an indigenous way of practicing the Christian religion" (Les Nouvelles de Tahiti, 20 May 2008).

7 Rognon's work reminds us that a century earlier, some white missionaries were already beginning the search for "vestiges" of a possible prior knowledge of the Truth in the myths and oral traditions of the Melanesians (the Marist priests' degeneration theory) or, in the case of the preachers from the London Missionary Society, developing a perception of paganism as a "state of waiting for the Gospel ... absorbed by so many seeds just waiting to flourish" (I99I, 30). For more "mythological links" in Eastern Polynesia, see also Saura 2004, $3 \mathrm{I}-55$.

8 On 28 August 20I4, the head of Ataï was handed over by the French authorities to a delegation of Kanak representatives from La Foa during a ceremony held at the Muséum National d'Histoire Naturelle in Paris.

9 Merle contrasted the "magnified remembrance" of the descendants of free settlers with the "absence of remembrance" of the descendants of convicts, where the "fault" of the ancestor is often repressed or minimized, relativized (I995, 368). See also Debien-Vanmai 2003.

Io For a discussion of the battles of I 844 and I 846 in the Society Islands, see Baré I987, 257-260; Gleizal 2005, 73-74.

I I In La Dépêche de Tahiti ( 77 Feb 20I I), Louise Lebreton wrote of the jibes that she endured in her childhood, "Teraupoo upo 'o 'ino" (Teraupoo crazy head).

I 2 See http://tamariimururoa.over-blog.com.

I3 Muckle wrote, "Some Kanaks see historians as potential spies looking for signs of division" (2012, I 82). On the manipulation of history and its local functions or uses in the context of New Caledonia, see also Naepels I998.

\section{References}

ADCK, Agence pour le Développement de la Culture Kanak

2008 La Guerre Kanak de I917. Mwà Véé: Revue culturelle Kanak 62 (October).

André, Sylvie

2008 Le Roman autochtone dans le Pacifique sud: Penser la continuité. Paris: L'Harmattan.

André, Sylvie, and Adriano Marchetti, editors

2004 Littératures du Pacifique: Voix francophones contemporaines. Rimini, Italy: Panozzo Editore. 
Angleviel, Frédéric

2006 Histoire de la Nouvelle-Calédonie: Nouvelles approches, nouveaux objets. Paris: L'Harmattan.

Angleviel, Frédéric, editor

2007 Histoire de la Nouvelle-Calédonie: Approches croisées. Actes de la ı 6ème conférence de l'association des historiens du Pacifique. Vol I. Paris: Les Indes savantes.

Australian Indigenous Law Reporter

2002 Noumea Accord-Digest. Australian Indigenous Law Reporter 88.

Baré, Jean-François

I985 Le Malentendu Pacifique. Paris: Hachette.

I987 Tahiti, les temps et les pouvoirs: Pour une anthropologie historique du Tahiti post-européen. Paris: orstom.

Bensa, Alban, Yvon Kacué Goromoedo, and Adrian Muckle

2014 Les Sanglots de l'aigle pêcheur: Nouvelle-Calédonie, la guerre kanak de I9I7. Paris: Anacharsis.

Besse, Jean-Pierre

20ıо Interview with Teddy Tefaatau. La Dépêche de Tahiti, 24 January.

Biersack, Aletta, editor

I991 Clio in Oceania: Toward a Historical Anthropology. Washington DC: Smithsonian Institution Press.

Blanchard, Pascal, and Isabelle Veyrat-Masson

2010 Les Guerres de mémoires: La France et son histoire. Preface by Benjamin Stora. Paris: La Découverte/Poche.

Borofsky, Robert, editor

2000 Remembrance of Pacific Pasts: An Invitation to Remake History. Honolulu: University of Hawai'i Press.

Boubin-Boyer, Sylvette, editor

2008 Révoltes, conflits et guerres mondiales en Nouvelle-Calédonie et dans sa région. 2 vols. Paris: L'Harmattan.

Bouju, Jacky

I995 Tradition et identité: La tradition dogon entre traditionalisme rural

Candau, Joël

et néo-traditionalisme urbain. Enquête 2:95-I I 7.

I998 Mémoire et identité. Paris: Presses Universitaires de France (PUF).

Dauphiné, Joël

I989 Les Spoliations foncières en Nouvelle-Calédonie (I853-I913). Paris:

L'Harmattan.

Debien-Vanmai, Cynthia

2003 Tabou d'un passé: Le Bagne. In I 50 ans de mémoire collective calédonienne: Exposition septembre 2003, edited by Musée de la Ville de Nouméa, 46-5I. Nouméa: Musée de la Ville. 
Dening, Greg

I986 Possessing Tahiti. In Papers Presented to John Mulvaney, edited by C C Macknight and J Peter White. Special issue of Archaeology in Oceania 2I (I): I03-II8.

Douglas, Bronwen

I996 L'Histoire face à l'anthropologie: Le passé colonial indigène revisité. Genèses 23:I25-I44.

Dousset-Leenhardt, Roselène

I970 Colonialisme et contradictions: Etude sur les causes socio-historiques de l'insurrection de 1878 en Nouvelle-Calédonie. Paris: Mouton \& Co.

Driessen, $\mathrm{H} \mathrm{A} \mathrm{H}$

I982 Outriggerless Canoes and Glorious Beings: Pre-contact Prophecies in the Society Islands. Journal of Pacific History I 7 (I): 3-26.

EEPF, Église Evangélique de Polynésie Française, editor

I997 Une vie polynésienne, 5 mars I797-I997, Te oraraa porinetia, 5 no māti I797-I997. Papeete: EEPF/Haere Pō.

Ellis, William

I967 Polynesian Researches during a Residence of Nearly 8 Years in the Society and Sandwich Islands. 2 vols. London: Dawsons of Pall Mall. Reprint of I 859 edition (London: Fisher \& Jackson).

Fontanieu, Guillaume

20I3 La Restitution des mémoires: Une expérience humaine, une aventure juridique. Journal de la Société des Océanistes I36-I37:I03-I I 8.

Friesen, Steven J, editor

$200 \mathrm{I}$ Ancestors in Post-Contact Religion: Roots, Ruptures, and Modernity's Memory. Cambridge, ma: Harvard University Press.

Gallagher, John, and Ronald Robinson

I953 The Imperialism of Free Trade. The Economic History Review, and series 6 (I): I-I 5 .

Gleizal, Toriki

2005 La Colonisation française dans le Pacifique: Le Cas tahitien (I 842I 880). DEA (master's) thesis, Université Paris VII.

2009 La Colonisation française des Établissements Français de l'Océanie: Délimitation, représentations et spécificités de I 842 à I9I4. PhD thesis, Université de la Polynésie Française.

Gonschor, Lorenz

2008 Law as a Tool of Oppression and Liberation: Institutional Histories and Perspectives on Political Independence in Hawai'i, Tahiti Nui/French Polynesia, and Rapa Nui. Master's thesis, Pacific Islands Studies, University of Hawai'i at Mānoa. 
Guiart, Jean

I983 La Terre est le sang des morts: Nouvelle-Calédonie du passé au présent. Paris: Anthropos.

2012 Ergo Sum: Chronique d'une vie en zigzags. Papeete: Te Pito o te Fenua.

Hapaitahaa, Joany

2004 Mission et colonisation à Tahiti de I $842-\mathrm{I} 880$. PhD thesis, Université de Saint-Etienne.

Hartog, François

2003 Régimes d'historicité, présentisme et expérience du temps. La librairie du XXIe siècle. Paris: Seuil.

Henry, Teuira

I928 Ancient Tahiti. Bernice P Bishop Museum Bulletin 48. Honolulu: Bishop Museum.

Huguenin, Paul

2007 Raiatea la sacrée. Facsimile re-edition of the original I902 edition. Papeete: Société des Études Océaniennes/Haere Pō no Tahiti.

Humbert, Sophie

2003 Colonisation et christianisation de la Terre des Hommes (îles Marquises): Entente et résistance; Les Visages de la confrontation. DEA (master's) thesis, Université de la Polynésie française.

2009 Retour sur Pakoko, résistant marquisien délaissé. In Histoire de la Franconésie: Regards croisés sur le Pacifique sud, edited by Frédéric Angleviel, 33-44. Paris: Les Indes savantes.

Lal, Brij V, editor

I992 Pacific Islands History: Journeys and Transformations. Canberra: The Australian National University.

Latham, Linda

I978 La Révolte de I878: Nouméa. Nouméa: Publication de la Société d'Études Historiques de la Nouvelle-Calédonie.

Linnekin, Jocelyn

I997 Contending Approaches. In The Cambridge History of the Pacific Islands, edited by Donald Denoon with Stewart Firth, Jocelyn Linnekin, Malama Meleisea, and Karen Nero, 3-36. Cambridge, UK: Cambridge University Press.

McCormick, Eric Hall

I977 Omai: Pacific Envoy. Auckland: Auckland University Press; Oxford: Oxford University Press.

Merle, Isabelle

I995 Expériences coloniales: La Nouvelle-Calédonie (I853-I920). Paris: Belin.

I999 L'Histoire coloniale du Pacifique: Problèmes et débats de la recherche anglophone. In Le Pacifique, un monde épars, edited by Alban Bensa 
and Jean-Claude Rivierre, 49-73. Cahiers du Pacifique sud contemporain I. Paris: L'Harmattan.

Merle, Isabelle, and Michel Naepels, editors

2003 Les Rivages du temps: Histoire et anthropologie du Pacifique. Cahiers du Pacifique sud contemporain 3. Paris: L'Harmattan.

Mokaddem, Hamid

2008 Littératures calédoniennes: La Littérature océanienne francophone est-elle une littérature française? Marseille: Éditions Transit.

Morrison, James

I935 The Journal of James Morrison. London: The Golden Cockerel Press. Available online at www.fatefulvoyage.com [accessed 22 Nov 20I4]

Muckle, Adrian

20I2 Specters of Violence in a Colonial Context: New Caledonia, I9I7. Honolulu: University of Hawaici Press.

Naepels, Michel

I998 Histoires de terres kanakes: Conflits fonciers et rapports sociaux dans la région de Houaïlou (Nouvelle-Calédonie). Paris: Belin.

Nora, Pierre, editor

I984 Les Lieux de mémoire. Vol I: La République. Paris: Gallimard.

Pasturel-Shigetomi, Anne-Lise

2000 Raiatea I 8 I 8-I945: Permanences et ruptures politiques, économiques et culturelles. 3 vols. PhD thesis, Université de la Polynésie française.

Peltzer, Louise

I995 Lettre à Poutaveri. Papeete: Scoop.

Picard, Jean-Luc

2008 Mā'ohi tumu et hutu pāinu: La Construction identitaire dans la littérature contemporaine de Polynésie française. $\mathrm{PhD}$ Thesis, Université Paul Verlaine-Metz.

Pouira Lombardini, Annick

2003 L'Influence socio-politique de l'Église protestante dans la société polynésienne de I863 à 2003. PhD thesis, Université Française du Pacifique.

Raapoto, Duro

I989 Poroì i te nūnaa māitibia e te Atua. Papeete: EEPF.

Ramsay, Raylene

20I I Nights of Storytelling: A Cultural History of Kanaky-New Caledonia. Honolulu: University of Hawai'i Press.

$20 \mathrm{I} 4$ The Literatures of the French Pacific: Reconfiguring Hybridity. Liverpool: Liverpool University Press.

Ramsay, Raylene, editor

2010 Cultural Crossings: Negotiating Identities in Francophone and Anglophone Pacific Literatures / À la croisée des cultures: De la 
négociation des identités dans les littératures francophones et anglophones du Pacifique. Bilingual edition. Brussels: Peter Lang.

Regnault, Jean-Marc

I996 Te metua: L'Échec d'un nationalisme tahitien. Papeete: Polymages.

2003 Pouvanaa a Oopa, victime de la raison d'État: Les Documents parlent. Moorea: Les Éditions de Tahiti.

2006 La France à l'opposé d'elle-même: Essais d'histoire politique de l'Océanie. Moorea: Les Éditions de Tahiti.

Regnault, Jean-Marc, and Catherine Vannier

2009 Le Metua et le général: Un combat inégal. Moorea: Les Éditions de Tahiti.

Reilly, Michael

2005 Te 'Orama a Numangatini (The Dream of Numangatini) and the Reception of Christianity on Mangaia. In Vision and Reality in Pacific Religion, edited by Phyllis Herda, Michael Reilly, and David Hilliard, I06-I 25. Canberra: The Australian National University; Christchurch: University of Canterbury.

RI, Rebellyon.info: Site collaborative d'infos alternatives

20I4 Le 24 septembre, journée de deuil pour le peuple Kanak colonisé par les Français. 24 September. http://rebellyon.info/Le-24-septembre

Ricoeur, Paul -journee-de-deuil.html [accessed 25 Oct 20I4]

2000 La Mémoire, l'Histoire, l'Oubli. Paris: Le Seuil.

Rognon, Frédéric

I99I Conversion, syncrétisme et nationalisme: Analyse du changement religieux chez les Mélanésiens de Nouvelle Calédonie. PhD thesis, Université de Paris X.

Sahlins, Marshall

I985 Islands of History. Chicago: The University of Chicago Press.

I99I The Return of the Event, Again. In Clio in Oceania: Toward a Historical Anthropology, edited by Aletta Biersack, 37-99. Washington DC: Smithsonian Institution Press.

I995 How "Natives" Think: About Captain Cook, For Example. Chicago: The University of Chicago Press.

Salaün, Marie

2005 L’École indigène: Nouvelle-Calédonie, I885-I945. Rennes: Presses Universitaires de Rennes.

Salmond, Anne

20I I Aphrodite's Island: The European Discovery of Tahiti. Oakland: University of California Press.

Saura, Bruno

I997 Pouvanaa Oopa, père de la culture politique tahitienne. Avec le jour- 
nal de Pouvanaa pour les années 1942-1944. Tahitian translation by Valérie Gobrait. Papeete: Au Vent des Îles.

I998 The Emergence of an Ethnic Millenarian Thinking, and the Development of Nationalism in Tahiti. Pacific Studies 2I (4): 33-66.

2004 La Société tahitienne au miroir d'Israël: Un peuple en métaphore. Paris: CNRS Éditions.

2008 Tahiti Ma'ohi: Culture, identité, religion et nationalisme en Polynésie française. Papeete: Au Vent des Îles.

Saussol, Alain

I985 Colonisation et problème foncier en Nouvelle-Calédonie. 3 vols. $\mathrm{PhD}$ thesis, Université Bordeaux 3.

Simmons, Laurence

$20 \mathrm{I} 2$ Tuhituhi: William Hodges, Cook's Painter in the South Pacific. Dunedin: Otago University Press.

Stora, Benjamin

2007 La Guerre des mémoires: La France face à son passé colonial. Paris: L'Aube.

Sultan, Patrick

20I I La Scène littéraire postcoloniale. Paris: Le Manuscrit.

Thomas, Nicholas

I989 Out of Time: History and Evolution in Anthropological Discourse. Cambridge, UK: Cambridge University Press.

Vigier, Stéphanie

20 I La Fiction face au passé: Histoire, mémoire et espace-temps dans la fiction littéraire océanienne contemporaine. Limoges: Pulim.

Wachtel, Nathan

I97 I The Vision of the Vanquished: The Spanish Conquest of Peru through Indian Eyes, I530-I 570. New York: Barnes \& Noble.

White, Geoffrey M, David Gegeo, Karen Ann Watson-Gegeo, and David Akin, editors

I988 The Big Death: Solomon Islanders Remember World War II. Honiara: Solomon Islands College of Higher Education; Suva: University of the South Pacific.

White, Geoffrey M, and Lamont Lindstrom, editors

I989 The Pacific Theater: Island Representations of World War II. Pacific Islands Monograph Series 8. Honolulu: Center for Pacific Islands Studies and University of Hawai'i Press.

Young, Michael W

I996 Commemorating Missionary Heroes: Local Christianity and Narratives of Nationalism. In Narratives of Nation in the South Pacific, edited by Ton Otto and Nicholas Thomas, 9I-I32. Amsterdam: Harwood Academic Publishers. 


\section{Abstract}

Beginning with an attempt to define "colonial times" and the "colonial past," this article examines the question of indigenous remembrance or remembrances of the past in the Pacific region-a subject that lies at the heart of the collaboration between disciplines of history and anthropology. The situations of the two main French colonies in the region-New Caledonia and French Polynesia-are quite different. What is similar is that, in both cases, indigenous peoples do not seem very interested in the period of first contact with Western navigators, and both tend to cast the evangelical work of nineteenth-century missionaries in a positive light. But colonial experiences in the two places are given distinctly different representations. New Caledonia has a violent past, with opposition between Kanak groups and French settlers as well as between some groups of Kanak. For this reason, it is necessary for work of remembrance to take place before a strong path toward the future, in the spirit of the Matignon and Nouméa accords, can be developed. In French Polynesia, on the other hand, the colonial wars of the nineteenth century have only recently begun to be a subject of public interest, but the period of nuclear tests (1966-I996) is still fresh in the collective memory. This period is the main reason for the tension in French Polynesia's relations with the French State, which, for members of the independence movement (and others), makes it impossible to forget and difficult to forgive.

KEYWORds: French Polynesia, New Caledonia, history, memory, colonization 